\title{
Evaluasi Program Pengendalian Leptospirosis di Kabupaten Gunungkidul Tahun 2017
}

\section{LATAR BELAKANG}

Leptospirosis adalah suatu infeksi zoonosis global yang disebarkan melalui air yang disebabkan oleh bakteri dari genus Leptospira. Data surveilans Dinas Kesehatan Kabupaten Gunungkidul menunjukkan bahwa ada peningkatan kasus leptospirosis pada tahun 2017 dibandingkan dengan tahun 2016. Pada tahun 2016, terdapat tujuh kasus leptospirosis, sedangkan pada bulan Januari-Juli 2017 terdapat 58 kasus leptospirosis yang tersebar di delapan wilayah kecamatan. Dari 58 kasus terdapat 16 kasus yang meninggal dan case fatality rate (CFR) $27.58 \%$. Keterlambatan dalam deteksi dini merupakan faktor penting dalam tingginya CFR

\section{TUJUAN}

Evaluasi yang dilakukan bertujuan untuk mengetahui gambaran dan permasalahan pelaksanaan program pengendalian leptospirosis di Kabupaten Gunungkidul tahun 2017.

\section{METODE}

Ini adalah penelitian deskriptif yang berfokus pada input, process dan output dari program pengendalian leptospirosis. Data dikumpulkan dengan mewawancarai petugas leptospirosis di Dinas Kesehatan Kabupaten Gunungkidul dan sebelas puskesmas yang memiliki kasus leptospirosis pada tahun 2017 dengan menggunakan kuesioner dan lembar observasi. Peneltian dilakukan selama bulan Mei sampai September 2017

\section{HASIL}

Program pengendalian leptospirosis merupakan bagian dari program zoonosis yang baru dibentuk pada bulan Maret 2017. Hasil evaluasi pada aspek input, semua petugas zoonosis sudah mendapatkan pelatihan walaupun didapatkan setelah puncak kasus pada bulan Januari-Juli tahun 2017; Dinas Kesehatan Kabupaten Gunungkidul sudah mengusahakan dengan optimal ketersediaan Rapid Diagnostic Test (RDT) untuk puskesmas yang ada kasus leptospirosis; Belum adanya keseragaman form Penyelidikan Epidemiologi. Pada aspek process, belum adanya perencanaan untuk kegiatan pengendalian leptospirosis karena merupakan program baru, kegiatan penyuluhan dilakukan pada saat Penyelidikan Epidemiologi (PE). Pada aspek output, semua kasus sudah dilakukan PE dan tercatat, hanya ada satu puskesmas yang tidak melakukan PE terhadap semua kasus leptospirosis, hal ini terjadi karena adanya tugas ganda dan kurangnya koordinasi petugas zoonosis dengan petugas surveilans di puskesmas.
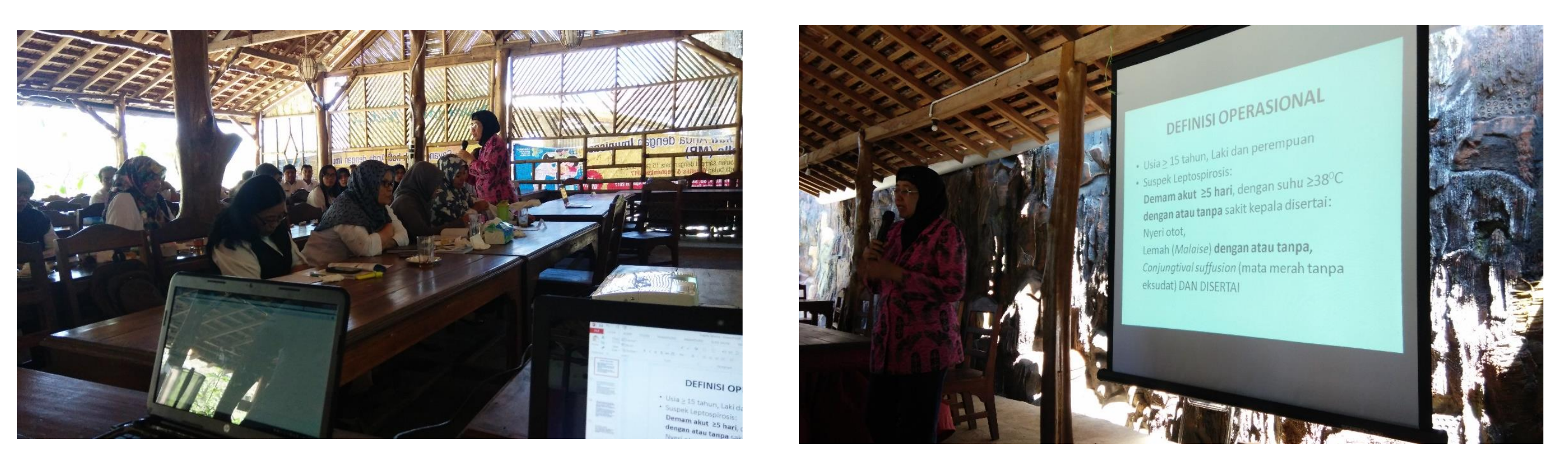

\section{Kesimpulan}

Program zoonosis terutama pengendalian leptospirosis telah dilaksanakan di Kabupaten Gunungkidul walaupun ada beberapa kelemahan pada input, prosess, dan output. Berdasarkan evaluasi, perlu dibuat perencanaan yang tepat untuk program pengendalian leptospirosis pada tahun 2018, keseragaman dalam pelaporan, dan peraturan yang baku dalam program pengendalian leptospirosis yang melibatkan program lintas sektoral.

\section{BIBLIOGRAPHY}

1. Chin, J , 2006. Manual Pemberantasan Penyakit Menular, diterjemahkan oleh .I Nyoman Kandun,, edisi, Depkes RI, Jakarta.

2. Fuadzy, H. 2013. Gambaran Penggunaan Rapid Diagnostic Test Parasit Malaria Di Desa Pasirmukti Kecamatan Cineam Kabupaten Tasikmalaya, Aspirator. Vol.5, No. 2, 2013 : 55-6

3. Indohun, 2014. Pedoman Aplikasi Hard Skill One Health. Depok: Indohun National Coordinating Health.
Office
Kemenk

4. Kemenkes RI, 2011. Buku Pedoman Penyelidikan dan Penanggulangan Kejadian Luar Biasa Penyakit Menular dan Keracunan Pangan. Jakarta :Sub Dirjen PP dan PL

5. Zulkoni Akhsin. 2011. Parasitologi. Yogyakarta Nuha Medika.

\section{7rd (2) Public Health

